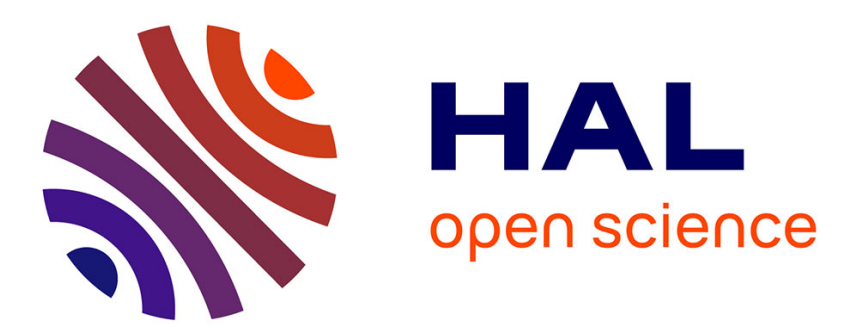

\title{
Prospective comparative study of characteristics associated with influenza $A$ and $B$ in adults
}

A. Chagvardieff, N. Persico, C. Marmillot, S. Badiaga, R. Charrel, A. Roch

\section{To cite this version:}

A. Chagvardieff, N. Persico, C. Marmillot, S. Badiaga, R. Charrel, et al.. Prospective comparative study of characteristics associated with influenza A and B in adults. Médecine et Maladies Infectieuses, 2018, 48 (3), pp.180-187. 10.1016/j.medmal.2017.11.007 . hal-02005997

\section{HAL Id: hal-02005997 https://hal-amu.archives-ouvertes.fr/hal-02005997}

Submitted on 12 Apr 2019

HAL is a multi-disciplinary open access archive for the deposit and dissemination of scientific research documents, whether they are published or not. The documents may come from teaching and research institutions in France or abroad, or from public or private research centers.
L'archive ouverte pluridisciplinaire HAL, est destinée au dépôt et à la diffusion de documents scientifiques de niveau recherche, publiés ou non, émanant des établissements d'enseignement et de recherche français ou étrangers, des laboratoires publics ou privés. 


\title{
Prospective comparative study of characteristics associated with influenza $A$ and $B$ in adults
}

\section{Étude prospective comparative des caractéristiques cliniques et biologiques des grippes $A$ et $B$ chez l'adulte}

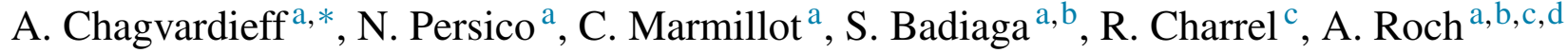 \\ ${ }^{a}$ Service d'accueil des urgences adultes, CHU Nord, chemin des Bourrely, 13915 Marseille cedex 20, France \\ ${ }^{\mathrm{b}}$ URMITE, CNRS-IRD, UMR 6236/198, Aix-Marseille université, pôle des maladies infectieuses, IHU, Méditerranée infection, 19-21 bd Jean Moulin, 13005 \\ Marseille, France \\ ${ }^{c}$ Aix-Marseille, université, UMR190 « Émergence des pathologies virales » (AMU-IRD-EHESP), 27 bd Jean Moulin, 13005 Marseille, France \\ dinserm 1095, URMITE, UM63, CNRS 7278, IRD 198, Aix-Marseille université, 27 bd Jean Moulin, 13005 Marseille, France
}

Received 5 December 2016; accepted 23 November 2017

Available online 17 December 2017

\begin{abstract}
Objectives. - To describe and compare the epidemiological characteristics associated with influenza type A and B as well as the characteristics associated with influenza pneumonia. The secondary objective was to evaluate the performance of influenza rapid diagnostic tests (RDT) in the emergency department.

Patients and methods. - Prospective study, including 251 adult patients admitted to the emergency department during the 2013-2014 influenza outbreaks for flu-like illness confirmed by RT-PCR.

Results. - A total of 106 patients were infected with influenza type B (42\%) and 145 with influenza type A (58\%). Mean age was 56 and the sex-ratio was 0.9 . In a multivariate analysis, the only factor independently related with the type of influenza strain was the patient's age. Overall, $17 \%$ of influenza-infected patients were vaccinated and $38 \%$ presented with pneumonia, with no significant difference between strains. In a univariate analysis, the risk factors associated with the occurrence of pneumonia were age, vaccination, and chronic obstructive pulmonary disease. Only $22 \%$ of samples positive by RT-PCR for influenza B and $40 \%$ for influenza A were positive by RDT.

Conclusion. - Influenza type A and type B had similar clinical and biological signs, including severity. Influenza type B should not be neglected. Any emergency department may use the RDT for its ease-of-use and rapidity. However, its low sensitivity should be taken into consideration when interpreting results.
\end{abstract}

(C) 2017 Elsevier Masson SAS. All rights reserved.

Keywords: Rapid diagnostic test; Epidemiology; Influenza; Pneumonia

\section{Résumé}

Objectifs. - Décrire et comparer les caractéristiques épidémiologiques associées aux grippes A et B et les facteurs associés à la pneumonie grippale. L'objectif secondaire était d'évaluer la performance du test de diagnostic rapide de la grippe aux urgences.

Patients et méthodes. - Étude prospective ayant inclus 251 patients adultes admis dans un service d'urgence pour syndrome grippal dont le diagnostic a été confirmé par RT-PCR au cours des épidémies 2013 et 2014.

Résultats. - Au total, 106 patients étaient atteints par la grippe B (42\%) et 145 par la grippe A (58\%), avec un âge moyen de 56 ans et un sex-ratio de 0,9. En analyse multivariée, seul l'âge du patient était considéré comme un facteur indépendant du type de souche grippale. Dix-sept pour cent

\footnotetext{
* Corresponding author at: Service d'accueil des urgences, hôpital Nord, chemin des Bourrely, 13915 Marseille cedex 20, France.

E-mail address: alexandre.chagvardieff@ap-hm.fr (A. Chagvardieff).
} 
des patients atteints de grippe étaient vaccinés et $38 \%$ avaient une pneumonie, sans différence significative entre les souches. En analyse univariée, les facteurs de risque associés à une pneumonie étaient l'âge, la vaccination et la bronchopneumopathie chronique obstructive. Seulement $22 \%$ des échantillons positifs en RT-PCR pour la grippe B et $40 \%$ pour la grippe A étaient positifs au test de diagnostic rapide.

Conclusion. - Les grippes A et B présentaient des manifestations cliniques et biologiques similaires, y compris leur gravité. La grippe B ne devrait pas être sous-estimée. Aux urgences, le test de diagnostic rapide est intéressant à réaliser, mais son résultat doit être interprété avec prudence compte tenu de sa faible sensibilité.

(C) 2017 Elsevier Masson SAS. Tous droits réservés.

Mots clés : Épidémiologie ; Grippe ; Pneumonie ; Test de diagnostic rapide

\section{Introduction}

Influenza is a contagious acute respiratory infection caused by an orthomyxoviridae, i.e. Myxovirus influenzae. It is responsible for annual epidemics across Europe and remains endemic in Asia. Three strains have been described mainly in human diseases: $\mathrm{A}, \mathrm{B}$, and $\mathrm{C}$, the latter occurring only sporadically. The World Health Organization (WHO) estimations of severe cases range from 3 to 5 million, and the number of deaths per year worldwide between 250,000 and 500,000. Influenza is a major socio-economical issue [1]. Clinically, the influenza or "flu syndrome" is usually very difficult to distinguish from other mild respiratory pathogens. Influenza type A, commonly accepted as highly pathogenic, caused several pandemics worldwide over the past few years [2,3]. Few studies compared illnesses caused by different subtypes of influenza, especially among adults $[4,5]$. Some of them suggested that influenza type B may be less severe [6]. More recently, a study conducted with patients admitted to emergency wards for reverse transcription polymerase chain reaction (RT-PCR)-confirmed influenza revealed that influenza A (H3N2) occurred more frequently among elderly and comorbid patients than influenza type B [7]. Other studies of outpatients presenting with confirmed influenza infections reported that A and B subtype influenza illnesses were similar with regards to clinical features [8] and severity assessed by the hospitalization rate [9]. The 2012-2013 seasonal outbreak in France was marked by a very high rate of influenza type $\mathrm{B}$ whereas the virus type A caused most of flu cases during the 2013-2014 outbreak [10]. Therefore, the main study goal was to compare the clinical characteristics of influenza types A and $\mathrm{B}$ among adults admitted to an emergency department during these two outbreaks. The influenza pneumonia-associated factors were described. Although the technical reference for virological diagnosis of influenza is RT-PCR [11], point-of-care rapid diagnostic tests (RDT) for influenza A and B viruses have been developed and are useful to guide the immediate care since antiviral drugs are available. The development of these tests in the emergency setting might depend on their real-life diagnostic accuracy and may vary by virus type. Therefore, we also aimed to compare the performance of RDT versus RT-PCR test for the two virus types.

\section{Patients and methods}

\subsection{Study design and patient population}

This observational prospective study was conducted in the emergency department of the tertiary care Northern Hospital, Marseilles, France, during the influenza outbreaks of 2013 (from December 1, 2012 to March 30, 2013) and 2014 (from December 1, 2013 to March 30, 2014). Study data was collected electronically for all adult patients presenting with influenza-like illness (defined as the sudden onset of fever $\left[\geq 37.8^{\circ} \mathrm{C}\right]$ and the presence of at least one of the following respiratory symptoms: cough, sore throat, or rhinorrhea/nasal obstruction [12-14]). All patients with RT-PCR-confirmed influenza from nasopharyngeal samples were included. The protocol was approved by the local research ethics committee, highlighting the need for informed consent to comply with the French legislation.

\subsection{Data collection}

The demographic and epidemiological data of every patient was collected: age, gender, comorbidities, anti-influenza vaccination status, previous treatments with anti-inflammatory drugs (steroidal or non-steroidal), and pre-admission antibiotic and/or antiviral treatment. Clinical data collected on admission were temperature, blood pressure, heart rate (HR), respiratory rate (RR), oxygen saturation ( $\mathrm{SpO} 2$ ), Glasgow coma scale score, and the presence of confusion. If required, biological tests were performed and included white blood cell count, C-reactive protein, procalcitonin, renal and hepatic function tests, serum sodium and glucose levels, blood gas analysis, and chest X-ray imaging blindly interpreted by a radiologist. Any administration of antibiotics and/or antiviral treatment at the emergency department, and their prescription at discharge or during hospital stay were recorded. The diagnosis of pneumonia was defined as the association of at least two of the following criteria: cough, production of purulent sputum, temperature $>38^{\circ} \mathrm{C}$ or $<36^{\circ} \mathrm{C}$, dyspnea, tachypnea or hypoxemia, with at least one of the following: auscultatory findings consistent with pneumonia, new or increased infiltrate on chest X-ray imaging (diagnostic criteria from the French Infectious Diseases Society guidelines for management of community-acquired pneumonia in adults) $[15,16]$. 


\subsection{Detection of respiratory viruses}

The nasal sample was taken using a Virocult ${ }^{\circledR}$ swab. The patient's head was put in hyperextension and the swab was inserted horizontally, parallel to the plane surface of the palate, around five to seven centimeters deep to reach the posterior and upper part of the nasopharynx. Careful swabbing was performed, deep and supported by a slow rotation against the nasal wall to detach the cells. The swab was then removed and immediately introduced into a canister. A rapid influenza diagnostic test was performed with the BD Directigen ${ }^{\mathrm{TM}}$ EZ Flu A + B test (BD diagnostic, USA) in association with a real-time polymerase chain reaction assay on nasal swabs.

\subsection{Statistical analysis}

Descriptive statistics included frequency analysis (percentages) for categorical variables and means and standard deviations for continuous variables. Comparisons used Fisher's exact test for categorical variables and Student's $t$ test for continuous variables. Factors independently associated with the virus subtype and occurrence of pneumonia were determined by the use of a logistic regression analysis. A $P$ value $<0.05$ was considered statistically significant. Statistical analysis was performed using SPSS 21.0 software (SPSS, Chicago, IL, USA).

\section{Results}

A total of 251 patients were included (Table 1): 106 patients presenting with influenza type B and 145 with influenza type A. Among the latter, 38 were infected with the H1N1 virus, 119 with $\mathrm{H} 3 \mathrm{~N} 2$, and 12 with both.

\subsection{Comparing influenza $A$ and $B$ patients}

The univariate analysis (Table 1) showed that type B-infected patients were older and had a higher respiratory rate. Type Ainfected patients had a higher heart rate, a higher white blood cell count, and a higher lactate level. Antiviral treatment at the emergency department was more often prescribed for type A-infected patients $(21 \%$ vs. $3.8 \%, P<0.01)$. Pneumonia was present at admission in $56(38.6 \%)$ type A-infected patients and $39(36.8 \%)$ type $\mathrm{B}$-infected patients $(P=0.77)$. The multivariate logistic regression analysis showed that none of the demographic, clinical, and biological parameters were statistically different between type A- and type B-infected patients.

\subsection{Characteristics of patients presenting with influenza pneumonia}

A total of 95 patients (38\%) out of 251 presented with pneumonia at admission. Table 2 details the demographic and epidemiological characteristics of patients presenting with and without pneumonia. The univariate analysis showed that pneumonia-affected patients were older, more often lived in institutions, and were more frequently affected with chronic obstructive pulmonary disease (COPD) or asthma.
A multivariate analysis highlighted a single potential risk factor for influenza pneumonia significantly associated with the occurrence of pneumonia for influenza-infected patients, i.e. age over 65 years (OR: $1.89,95 \%$ CI: 1.05-3.40). Table 3 details the clinical and biological characteristics as well as clinical outcomes of patients presenting with and without pneumonia.

\subsection{Diagnostic accuracy of rapid influenza test}

The sensitivity of the rapid diagnostic test was better for type A-infected patients than for type B-infected patients (40\% vs. $22 \%, P=0.001$ ) (Table 4).

\section{Discussion}

This prospective study highlights the existence of minor epidemiological differences in influenza infections caused by strains $\mathrm{A}$ and $\mathrm{B}$ but no difference in clinical severity was observed. Influenza type A and B infections may go through pneumonia-related complications in a similar pattern, especially for patients over 65 years.

In 2014, Glezen et al. described a significant change in the epidemiology of influenza type $B$ with the rise in the mid1980 s of two antigenically distinct lineages represented by B/Victoria/2/87 and B/Yamagata/16/88 [17].

Since 2001, seasonal outbreaks worldwide have been caused by both type A and B strains, albeit in a variable scale but hardly predictable. This may explain why comparative studies between type A and B strains are scarce. The present study took place in a context of recurrent and sometimes tough influenza outbreaks, particularly in an emergency department.

The mean age of our study population was 56, while previously described populations were usually younger: 32 years for the 2012 flu outbreak and 19 years for the 2011 outbreak [18]. This discrepancy might be explained by the recruitment methodology: unlike most of the younger patients, patients included in the current study had to come to the emergency department. Interestingly, the current study revealed that type B-infected patients were older than type A-infected ones (OR: 0.95, 95\% CI: 0.89-1.01). This is different from previously reported data $[19,20]$. However, cohorts of the latter studies, unlike ours, included children. Excluding the pediatric population in those studies, influenza type B seems more frequent, which may explain the observed discrepancy. As previously reported, the gender was not a meaningful factor of differentiation [21]. In a 2014 multicenter study, Su et al. described similar morbidity and mortality rates among patients hospitalized for influenza type A or B who received antiviral treatment. The authors concluded that therapeutic measures should not differ depending on the strain at play [22]. However, two additional studies, published in 2006 and 2007, reported a reduction in the effectiveness of oseltamivir against influenza type B compared with type A, marked by persistent fever and re-isolation of the virus despite treatment with neuraminidase inhibitors $[23,24]$. Other studies also reported the lower sensitivity to neuraminidase inhibitors in type B-infected patients compared with type-A patients $[25,26]$. 
Table 1

Comparison of factors associated with influenza type A and B in 251 patients by univariate and multivariate analyses.

Comparaison des caractéristiques associées aux grippes A et $B$ des 251 patients en analyses univariée et multivariée.

\begin{tabular}{|c|c|c|c|c|c|}
\hline Characteristics & $\begin{array}{l}\text { Influenza A } \\
(n=145)\end{array}$ & $\begin{array}{l}\text { Influenza B } \\
(n=106)\end{array}$ & $\begin{array}{l}P \text { value Univariate } \\
\text { analysis }\end{array}$ & Odds ratio $95 \% \mathrm{CI}$ & $\begin{array}{l}P \text { value Multivariate } \\
\text { analysis }\end{array}$ \\
\hline \multicolumn{6}{|l|}{ Demographics } \\
\hline $\operatorname{Sex}-n(\%)$ & & & 0.86 & & \\
\hline Men, $n(\%)$ & $70(48.3)$ & $50(47.2)$ & & & \\
\hline Women, $n(\%)$ & $75(51.7)$ & $56(52.8)$ & & & \\
\hline Age, mean (SD) & $54 \pm 24$ & $60 \pm 22$ & 0.03 & $0.95[0.89-1.01]$ & 0.10 \\
\hline Vaccination, $n(\%)$ & $24(19.2)$ & $19(17.9)$ & 0.80 & & \\
\hline \multicolumn{6}{|l|}{ Comorbidities, $n(\%)$} \\
\hline Institutionalization & $9(6.2)$ & $5(4.7)$ & 0.57 & & \\
\hline COPD/Asthma & $41(29.7)$ & $27(25.5)$ & 0.46 & & \\
\hline Chronic respiratory failure & $5(3.6)$ & $4(3.8)$ & 0.96 & & \\
\hline Chronic heart failure & $10(9.8)$ & $0(0)$ & 0.74 & & \\
\hline Coronary disease & $20(14.2)$ & $11(10.4)$ & 0.37 & & \\
\hline Obesity & $8(5.8)$ & $7(6.6)$ & 0.81 & & \\
\hline Diabetes & $17(12.3)$ & $16(5.1)$ & 0.53 & & \\
\hline Current neoplasia & $3(2.2)$ & $7(6.6)$ & 0.11 & & \\
\hline Cured neoplasia & $6(4.3)$ & $7(6.6)$ & 0.44 & & \\
\hline Stroke & $7(5.1)$ & $6(5.7)$ & 0.85 & & \\
\hline Chronic renal failure & $5(3.6)$ & $5(4.7)$ & 0.75 & & \\
\hline Immunosuppression & $2(1.5)$ & $4(3.8)$ & 0.41 & & \\
\hline Chronic liver disease & $3(2.2)$ & $1(0.9)$ & 0.63 & & \\
\hline Pregnancy & $4(2.9)$ & $0(0)$ & 0.14 & & \\
\hline \multicolumn{6}{|l|}{ Clinical features } \\
\hline Glasgow coma scale $<15, n(\%)$ & $7(5)$ & $5(4.7)$ & 0.92 & & \\
\hline Hyperthermia $>38^{\circ} \mathrm{C}, n(\%)$ & $84(60.4)$ & $66(62.3)$ & 0.32 & & \\
\hline Hypothermia $<36^{\circ} \mathrm{C}, n(\%)$ & $8(5.8)$ & $2(1.9)$ & 0.32 & & \\
\hline Delirium, $n(\%)$ & $9(6.5)$ & $5(4.7)$ & 0.55 & & \\
\hline Respiratory rate (c/min), mean (SD) & $21 \pm 6$ & $25 \pm 6$ & 0.02 & $0.86[0.73-1.01]$ & 0.07 \\
\hline Systolic blood pressure $(\mathrm{mmHg})$, mean $(\mathrm{SD})$ & $131 \pm 23$ & $134 \pm 24$ & 0.23 & & \\
\hline Heart rate $(\mathrm{b} / \mathrm{min})$, mean $(\mathrm{SD})$ & $98 \pm 20$ & $92 \pm 16$ & 0.02 & $1.03[0.98-1.07]$ & 0.23 \\
\hline $\mathrm{SpO} 2(\%)$, mean $(\mathrm{SD})$ & $96 \pm 4$ & $96 \pm 4$ & 0.80 & & \\
\hline \multicolumn{6}{|l|}{ Biological tests, mean $\pm \mathrm{SD}$} \\
\hline White blood cells (Giga/L) & $8.5 \pm 4$ & $7.3 \pm 3.2$ & 0.02 & $1.28[1.00-1.63]$ & 0.06 \\
\hline Neutrophil (Giga/L) & $6.8 \pm 4$ & $5.7 \pm 3$ & 0.02 & & \\
\hline Hematocrit (\%) & $39 \pm 5$ & $39 \pm 5$ & 0.69 & & \\
\hline Natremia (mmol/L) & $139 \pm 4$ & $139 \pm 4$ & 0.87 & & \\
\hline Glycemia (mmol/L) & $6.6 \pm 2.4$ & $6.6 \pm 2.3$ & 0.77 & & \\
\hline Urea $(\mathrm{mmol} / \mathrm{L})$ & $6.6 \pm 6$ & $6.9 \pm 4$ & 0.68 & & \\
\hline Creatinine $(\mathrm{mmol} / \mathrm{L})$ & $80 \pm 43$ & $87 \pm 44$ & 0.23 & & \\
\hline $\mathrm{CRP}(\mathrm{mg} / \mathrm{L})$ & $66 \pm 72$ & $53 \pm 65$ & 0.16 & & \\
\hline PCT $(\mu \mathrm{g} / \mathrm{L})$ & $1.26 \pm 5.6$ & $2.33 \pm 5$ & 0.44 & & \\
\hline $\mathrm{PaO} 2(\mathrm{mmHg})$ & $81 \pm 27$ & $89 \pm 40$ & 0.2 & & \\
\hline Lactate $(\mathrm{mmol} / \mathrm{L})$ & $1.7 \pm 1$ & $1.2 \pm 0.5$ & 0.002 & $2.07[0.65-6.67]$ & 0.22 \\
\hline Pathological chest X-ray, $n(\%)$ & $50(39.7)$ & $40(37.7)$ & 0.76 & & \\
\hline \multicolumn{6}{|l|}{ Emergency treatment, $n(\%)$} \\
\hline Antibiotic & $69(49.6)$ & $50(47.2)$ & 0.70 & & \\
\hline Oseltamivir & $29(21)$ & $4(3.8)$ & $<0.01$ & & \\
\hline Oxygen therapy & $46(33.6)$ & $32(30.2)$ & 0.575 & & \\
\hline \multicolumn{6}{|l|}{ Outcome, $n(\%)$} \\
\hline Pneumonia & $56(38.6)$ & $39(36.8)$ & 0.77 & & \\
\hline Hospitalization & $90(62.1)$ & $51(48.1)$ & 0.03 & & \\
\hline ICU admission & $6(4.1)$ & $3(2.8)$ & 0.74 & & \\
\hline Death & $4(2.8)$ & $1(1)$ & 0.40 & & \\
\hline
\end{tabular}

COPD: chronic obstructive pulmonary disease; CRP: C-reactive protein; PCT: procalcitonin; ICU: intensive care unit; SD: standard deviation.

In the current study, the diagnosis of pneumonia was limited to $95(38 \%)$ of the 251 patients. No significant difference in the virus strain was reported $(38.6 \%$ vs. $36.8 \% P=0.77$ for influenza type $\mathrm{A}$ and $\mathrm{B}$, respectively). A shortage in accurate data on the incidence of pneumonia in type B-infected patients makes any comparison irrelevant. Most studies focused on pediatric populations. The number of patients hospitalized for pneumonia with influenza (irrespective of the strain) is however consistent with literature data [19]. The only risk factor independently associated with the occurrence of influenza pneumonia in our study was age: patients aged over 65 years had a risk almost twice higher than younger patients (OR: 1.89, 95\% CI: 1.05-3.40). 
Table 2

Comparison of demographic characteristics of patients presenting with and without influenza pneumonia by univariate and multivariate analyses.

Comparaison des caractéristiques démographiques des patients avec et sans pneumonie grippale en analyses univariée et multivariée.

\begin{tabular}{|c|c|c|c|c|c|}
\hline Characteristics & No pneumonia $(n=156)$ & Pneumonia $(n=95)$ & $\begin{array}{l}P \text { value Univariate } \\
\text { analysis }\end{array}$ & Odds ratio $95 \% \mathrm{CI}$ & $\begin{array}{l}P \text { value Multivariate } \\
\text { analysis }\end{array}$ \\
\hline \multicolumn{6}{|l|}{ Demographics } \\
\hline Men & $87(56)$ & $44(46)$ & & & \\
\hline Women & $69(44)$ & $51(54)$ & & & \\
\hline Age & & & 0.001 & & \\
\hline Median (SD) & $50.7 \pm 23$ & $65.6 \pm 20$ & & & \\
\hline \multicolumn{6}{|c|}{ Treatment before admission, $n(\%)$} \\
\hline NSAID & $16(11)$ & $10(11)$ & 0.97 & & \\
\hline Corticosteroids & $15(10)$ & $8(9)$ & 0.76 & & \\
\hline Anti-influenza drug & $2(1)$ & $2(2)$ & 0.61 & & \\
\hline Influenza vaccination & $21(14)$ & $22(26)$ & 0.04 & $1.29[0.60-2.79]$ & 0.52 \\
\hline \multicolumn{6}{|l|}{ Comorbidities, $n(\%)$} \\
\hline Coronary disease & $19(12)$ & $12(13)$ & 0.94 & & \\
\hline Obesity & $8(5)$ & $7(8)$ & 0.45 & & \\
\hline Diabetes & $17(11)$ & $16(17)$ & 0.17 & & \\
\hline Current neoplasia & $5(3)$ & $5(5)$ & 0.4 & & \\
\hline Cured neoplasia & $6(3)$ & $7(7)$ & 0.22 & & \\
\hline Stroke & $9(6)$ & $4(4)$ & 0.77 & & \\
\hline Chronic renal failure & $5(3)$ & $5(5)$ & 0.51 & & \\
\hline Immunosuppression & $4(2)$ & $2(2)$ & 0.83 & & \\
\hline Chronic liver disease & $2(1)$ & $2(2)$ & 0.63 & & \\
\hline Pregnancy & $4(3)$ & $0(0)$ & 0.3 & & \\
\hline
\end{tabular}

COPD: chronic obstructive pulmonary disease; NSAID: nonsteroidal anti-inflammatory drug; SD: standard deviation.

Our results on strain-related complications, hospitalization rate, intensive care unit transfer, and deaths are comparable with the latest epidemiological data [27]. These results suggest that influenza type B is not less severe than influenza type $\mathrm{A}$ and that it may also lead to complications [28].

The current study revealed the high prevalence of patients both vaccinated and affected by influenza, without any difference between the two strains ( $19.2 \%$ vs. $17.9 \%, P=0.80)$. Quite paradoxically, vaccination appears to be a pneumonia risk factor in univariate analysis $(25.6 \%$ vs. $14 \%, P=0.04)$. Even if the risk of death and serious complications are lower [29], the effectiveness of influenza vaccination might decrease, particularity for the elderly. Current studies investigate the relation between the immune response to immunization as measured by immunoassays and the subsequent occurrence of an influenza infection among the elderly. Thorough vaccination campaigns aimed at this population would significantly help to prevent any virus outbreak [30,31].

The trivalent vaccine, including a single strain of influenza $B$ virus, may not be adequate with the ongoing strain B, and the independent variability of these two lines jeopardizes cross-immunity [32]. This phenomenon is therefore likely to significantly undermine the clinical effectiveness of trivalent influenza vaccine. In the Northern Hemisphere during the 2013-2014 seasonal outbreak, the WHO recommended - for the first time - the composition of tetravalent influenza vaccines including two strains $A(\mathrm{H} 1 \mathrm{~N} 1$ and $\mathrm{H} 3 \mathrm{~N} 2)$ and two strains B (Victoria 2/87 and Yamagata 16/88). The purpose was to improve the protection against type $\mathrm{B}$ virus and reduce this strain-associated morbidity.

Several studies reported strong clinical evidence in favor of the use of RDT for an immediate influenza diagnosis. It allows for a rapid administration of antiviral drugs and reduces the rate of antibiotic prescription. Ultimately, it leads to fewer complications for patients and savings for the hospital $[33,34]$. The use of RDT in our study showed a very poor sensitivity ( $40 \%$ for strain A and $22 \%$ for strain B). These results stand below the theoretical performance characteristics announced by the manufacturer laboratory BD for its Directigen ${ }^{\mathrm{TM}} \mathrm{EZ}$ Flu $A+B$ (respectively $77 \%$ to $86 \%$ and $69 \%$ to $80 \%$ compared with cell culture). A 2012 meta-analysis of 159 studies evaluating the BD Directigen ${ }^{\mathrm{TM}}$ EZ Flu A + B test performance also observed a lower sensitivity (around 57\%) compared with cell culture or RT-PCR, with substantial variability [35]. This review also revealed the significant heterogeneity of the RDT sensitivity among influenza strains. In compliance with our own results and with literature data, the detection of type A virus had a higher sensitivity than type B virus [36]. Several factors may explain the poor sensitivity of RDT: the amount of antigen - varying with viral shedding -, the population [37], and the disease stage; the nasopharyngeal swab associated with higher sensitivity than nasopharyngeal aspiration; the quality of samples, 
Table 3

Clinical and biological characteristics and outcome of patients presenting with influenza pneumonia in univariate analysis.

Caractéristiques cliniques et biologiques et résultats des patients atteints de pneumonie grippale en analyse univariée.

\begin{tabular}{|c|c|c|c|}
\hline Characteristics & $\begin{array}{l}\text { No pneumonia } \\
(n=156)\end{array}$ & $\begin{array}{l}\text { Pneumonia } \\
(n=95)\end{array}$ & $P$ value \\
\hline \multicolumn{4}{|l|}{ Clinical features } \\
\hline Glasgow coma scale $<15$ & $6(4)$ & $6(6.5)$ & 0.37 \\
\hline $\begin{array}{l}\text { Hyperthermia }>38^{\circ} \mathrm{C}-n \\
(\%)\end{array}$ & $96(63.2)$ & $54(58.1)$ & 0.31 \\
\hline $\begin{array}{l}\text { Hypothermia }<36^{\circ} \mathrm{C}-n \\
(\%)\end{array}$ & $4(2.6)$ & $6(6.5)$ & 0.31 \\
\hline Cough $-n(\%)$ & $53(80)$ & $33(92)$ & 0.13 \\
\hline Purulent sputum $-n(\%)$ & $12(18)$ & $14(40)$ & 0.01 \\
\hline Dyspnea $-n(\%)$ & $16(25)$ & $26(68)$ & 0.001 \\
\hline Delirium $-n(\%)$ & $6(4)$ & $8(8.6)$ & 0.13 \\
\hline $\begin{array}{l}\text { Respiratory } \\
\text { rate/min - mean (SD) }\end{array}$ & $20 \pm 5$ & $23 \pm 6$ & 0.03 \\
\hline $\begin{array}{l}\text { Systolic blood pressure } \\
\mathrm{mmHg} \text { - mean (SD) }\end{array}$ & $132 \pm 22$ & $133 \pm 26$ & 0.68 \\
\hline $\begin{array}{l}\text { Heart rate/min - mean } \\
\text { (SD) }\end{array}$ & $96 \pm 18$ & $95 \pm 19$ & 0.68 \\
\hline $\mathrm{SpO} 2 \%$ - mean (SD) & $96 \pm 3$ & $95 \pm 5$ & 0.002 \\
\hline \multicolumn{4}{|l|}{ Laboratory tests - mean (SD) } \\
\hline White blood cells $-\mathrm{G} / \mathrm{L}$ & $7.4 \pm 3$ & $8.9 \pm 4$ & 0.007 \\
\hline Neutrophil-G/L & $5.8 \pm 3$ & $7.1 \pm 4$ & 0.01 \\
\hline Hemoglobin - g/dL & $10.9 \pm 5$ & $8.7 \pm 5$ & 0.04 \\
\hline Hematocrit - \% & $39 \pm 5$ & $38 \pm 5$ & 0.23 \\
\hline Natremia - mmol/L & $139 \pm 4$ & $139 \pm 5$ & 0.7 \\
\hline Glycemia - mmol/L & $6.4 \pm 2$ & $6.9 \pm 2$ & 0.12 \\
\hline Total bilirubin $-\mu \mathrm{mol} / \mathrm{L}$ & $10.5 \pm 7$ & $11 \pm 9$ & 0.7 \\
\hline ASAT - UI/L & $40 \pm 38$ & $55 \pm 76$ & 0.13 \\
\hline ALAT - UI/L & $36 \pm 14$ & $50 \pm 60$ & 0.09 \\
\hline ALKP - UI/L & $76 \pm 34$ & $85 \pm 27$ & 0.24 \\
\hline GGT - UI/L & $41 \pm 52$ & $86 \pm 171$ & 0.12 \\
\hline Urea - mmol/L & $5.7 \pm 3$ & $8.3 \pm 6$ & 0.001 \\
\hline creatinine $-\mathrm{mmol} / \mathrm{L}$ & $76 \pm 29$ & $93 \pm 57$ & 0.01 \\
\hline $\mathrm{CRP}-\mathrm{mg} / \mathrm{L}$ & $51 \pm 62$ & $75 \pm 72$ & 0.01 \\
\hline $\mathrm{PCT}-\mu \mathrm{g} / \mathrm{L}$ & $1.1 \pm 3.6$ & $2.2 \pm 7.5$ & 0.38 \\
\hline $\mathrm{PaO}_{2}-\mathrm{mmHg}$ & $81 \pm 27$ & $86 \pm 38$ & 0.43 \\
\hline $\mathrm{PaCO}_{2}-\mathrm{mmHg}$ & $35 \pm 6$ & $38 \pm 10$ & 0.03 \\
\hline $\mathrm{pH}$ & $7.47 \pm 0.05$ & $7.45 \pm 0.07$ & 0.01 \\
\hline Lactates - mmol/L & $1.4 \pm 0.6$ & $1.6 \pm 1$ & 0.2 \\
\hline \multicolumn{4}{|l|}{ Emergency treatment $-n(\%)$} \\
\hline Antibiotic & $53(35)$ & $66(70)$ & 0.001 \\
\hline Oseltamivir & $16(11)$ & $17(18)$ & 0.09 \\
\hline Oxygen therapy & $32(21)$ & $46(4)$ & 0.001 \\
\hline \multicolumn{4}{|l|}{ Outcome, $n(\%)$} \\
\hline Hospitalization & $71(45)$ & $70(73)$ & 0.001 \\
\hline ICU admission & $2(1)$ & $7(7)$ & 0.01 \\
\hline Death & $0(0)$ & $5(5)$ & 0.007 \\
\hline
\end{tabular}

CRP: C-reactive protein; ICU: intensive care unit; PCT: procalcitonin; SD standard deviation.

physician-dependent and affected by transportation conditions to laboratories.

The RDT is proven to be a quick way to diagnose influenza and initiate treatment. Its ease-of-use and rapidity fulfil the needs of emergency departments. However, its sensitivity is not satisfactory for it to be the only test performed. Despite its limited availability, the RT-PCR test remains the standard to safely confirm an influenza diagnosis. Combined RT-PCR and RDT tests
Table 4

Sensitivity of influenza rapid diagnostic test.

Sensibilité du test de diagnostic rapide de la grippe.

\begin{tabular}{|c|c|c|c|c|c|}
\hline \multirow{2}{*}{$\begin{array}{l}\text { Rapid test } \\
\text { result }\end{array}$} & \multirow{2}{*}{$\begin{array}{l}\text { Influenza } \\
\mathrm{B} n=106\end{array}$} & \multicolumn{4}{|c|}{ Influenza A $n=145$} \\
\hline & & $\begin{array}{l}\mathrm{H} 1 \mathrm{~N} 1 \\
n=22\end{array}$ & $\begin{array}{l}\mathrm{H} 3 \mathrm{~N} 2 \\
n=104\end{array}$ & $\begin{array}{l}\text { Co-infection } \\
n=19\end{array}$ & Total \\
\hline Positive & 23 & 10 & 36 & 12 & 58 \\
\hline Negative & 83 & 12 & 68 & 7 & 87 \\
\hline $\begin{array}{l}\text { Test sensi- } \\
\text { tivity }\end{array}$ & $22 \% *$ & $45 \%$ & 35 & $63 \%$ & $40 \% *$ \\
\hline
\end{tabular}

could be the best way to diagnose influenza in a rapid and reliable way in healthcare facilities [38].

\subsection{Limitations}

The study has several limitations. It was conducted in an emergency department and thus does not include outpatients, who are deemed younger and healthier. The H1N1 and H3N2 strains of influenza type A have been included in the same group, but they have not been compared with one another which might be a confounding factor.

The lack of patients with negative RT-PCR in our sample hampers the assessment of the RDT relevance. The test specificity and its positive predictive values were not evaluated.

\section{Conclusion}

Influenza type B is not less severe than influenza type A in adult population. Due to its significant morbidity, this strain should not be neglected; hence the importance of using tetravalent influenza vaccines. The assessment of emergency patients must first be based on age, comorbidities, clinical and paraclinical signs of severity rather than on the influenza strain.

The sensitivity of RDT remains clearly inadequate and its results should be cautiously used (high number of false negative results). There is still a strong potential for improvement of the quality of sampling techniques as well as for innovations in the field of rapid molecular tests. Despite its limitations, RDT should be used in emergency departments to isolate and treat patients as soon as possible.

\section{Contribution of authors}

A. Chagvardieff wrote the study protocol, analyzed the data and results, and wrote the article.

C. Marmillot collected the data and contributed to analyzing the results.

N. Persico, S. Badiaga and A. Roch contributed to reviewing and approving the article.

R. Charrel provided the virological tests and contributed to the article approval. 


\section{Funding}

No funding was received.

\section{Ethical approval}

This article does not contain any study with human participants or animals performed by any of the authors.

\section{Informed consent}

This study was declared to the local Ethical Review Committee and approved as per French legislation. Data was anonymously analyzed.

\section{Disclosure of interest}

The authors declare that they have no competing interest.

\section{Acknowledgement}

We would like to thank Dr Xavier Argemi (Strasbourg, France) for reviewing the article.

\section{References}

[1] World Health Organization Influenza. Fact sheet no. 211. 2016. [Cited 2005 Apr 25].

[2] Girard MP, Tam JS, Assossou OM, et al. The 2009 A (H1N1) influenza virus pandemic: a review. Vaccine 2010;28(31):4895-902.

[3] Reed C, Chaves SS, Perez A, et al. Complications among adults hospitalized with influenza: a comparison of seasonal influenza and the 2009 H1N1 pandemic. Clin Infect Dis 2014;59(2):166-74.

[4] Glezen WP, Schmier JK, Kuehn CM, et al. The burden of influenza B: a structured literature review. Am J Public Health 2013;103(3):e43-51.

[5] Gutierrez-Pizarraya A, Perez-Romero P, Alvarez R, et al. Unexpected severity of cases of influenza B infection in patients that required hospitalization during the first postpandemic wave. J Infect 2012;65:423-30.

[6] Taubenberger JK, Morens DM. The pathology of influenza virus infections. Annu Rev Pathol 2008;3:499-522.

[7] Wie SH, So BH, Song JY, et al. A comparison of the clinical and epidemiological characteristics of adult patients with laboratory-confirmed influenza A or B during the 2011-2012 influenza season in Korea: a multi-center study. PLoSOne 2013;8(5):e62685.

[8] Mosnier A, Caini S, Daviaud I, et al. GROG network. Clinical characteristics are similar across type A and B influenza virus infections. PLoS One 2015;10(9):e0136186

[9] Cohen JM, Silva ML, Caini S, et al. IBGP study team. Striking similarities in the presentation and duration of illness of influenza A and B in the community: a study based on sentinel surveillance networks in france and turkey, 2010-2012. PLoS One 2015;10(10):e0139431.

[10] Belchior E. Surveillance épidémiologique et virologique de la grippe en France métropolitaine, saison 2013-2014. Bull Epidemiol Hebd 2014;28:460-5.

[11] Smith AB, Mock V, Melear R, Colarusso P, Willis DE. Rapid detection of influenza A and $\mathrm{B}$ viruses in clinical specimens by Light Cycler real time RT-PCR. J Clin Virol 2003;28(1):51-8.

[12] Yang X, Yao Y, Chen M, Yang X, Xie Y, et al. Etiology and clinical characteristics of influenza-like illness (ILI) in outpatients in Beijing. June 2010 to May 2011. PLoS One 2012; 7:e28786.

[13] Woolpert T, Brodine S, Lemus H, Waalen J, Blair P, et al. Determination of clinical and demographic predictors of laboratory-confirmed influenza with subtype analysis. BMC Infect Dis 2012;12:129.
[14] Dai XQ, Liu M, Zhang TH, Yang XS, Li SL, et al. Clinical predictors for diagnosing pandemic (H1N1) 2009 and seasonal influenza (H3N2) in fever clinics in Beijing. China. Biomed Environ Sci 2012;25:61-8.

[15] Douwe F, Postma and CAP-START Study Group. Antibiotic treatment strategies for community-acquired pneumonia in adults. N Engl J Med 2015;372:1312-23.

[16] SPILF. Prise en charge des infections des voies respiratoires basses de l'adulte immunocompétent; conférence de consensus; 2006.

[17] Glezen WP. Changing epidemiology of influenza B virus. Clin Infect Dis 2014:ciu668.

[18] Équipes de surveillance de la grippe. Surveillance épidémiologique et virologique de la grippe en France, saison 2012-2013. Bull Epidemiol Hebd 2013;(32):394-401.

[19] Irving SA, Patel DC, Kieke BA, Donahue JG, Vandermause MF, Shay DK, et al. Comparison of clinical features and outcomes of medically attended influenza A and influenza B in a defined population over four seasons: 2004-2005 through 2007-2008. Influenza Other Respir Viruses 2012;6(1):37-43.

[20] Hinds AM, Bozat-Emre S, Van Caeseele P, Mahmud SM. Comparison of the epidemiology of laboratory-confirmed influenza A and influenza B cases in Manitoba, Canada. BMC Public Health 2015;15(1):35.

[21] Xu C, Iuliano AD, Chen $M$, et al. Characteristics of hospitalized cases with influenza A (H1N1) pdm09 infection during first winter season of post-pandemic in China. PloS one 2013;8(2):e55016.

[22] Su S, Chaves SS, Perez A, D’Mello T, Kirley PD, Yousey-Hindes K, et al. Comparing clinical characteristics between hospitalized adults with laboratory-confirmed influenza A and B virus infection. Clin Infect Dis 2014;59(2):252-5.

[23] Kawai N, Ikematsu H, Iwaki N, Kawashima T, Maeda T, Mitsuoka S, et al. Longer virus shedding in influenza B than in influenza $\mathrm{A}$ among outpatients treated with oseltamivir. J Infect 2007;55(3):267-72.

[24] Kawai N, Ikematsu H, Iwaki N, Maeda T, Satoh I, Hirotsu N, et al. A comparison of the effectiveness of oseltamivir for the treatment of influenza A and influenza B: a Japanese multicenter study of the 2003-2004 and 2004-2005 influenza seasons. Clin Infect Dis 2006;43(4):439-44.

[25] Hurt AC, McKimm-Breschkin JL, McDonald M, Barr IG, Komadina $\mathrm{N}$, Hampson AW. Identification of a human influenza type B strain with reduced sensitivity to neuraminidase inhibitor drugs. Virus Res 2004:103(1-2):205-11

[26] Farrukee R, Mosse J, Hurt AC. Review of the clinical effectiveness of the neuraminidase inhibitors against influenza B viruses. Expert Rev Anti Infect Ther 2013;11(11):1135-45.

[27] Cheng AC, Holmes M, Dwyer DE. Influenza epidemiology in patients admitted to sentinel Australian hospitals in 2015: the influenza complications alert network. Commun Dis Intell Q Rep 2016;40(4):E521-6.

[28] Paddock CD, Liu L, Denison AM, et al. Myocardial injury and bacterial pneumonia clinical microbiology and infection contribute to the pathogenesis of fatal influenza B virus infection. J Infect Dis 2012;205:895-905.

[29] Myles PR, Semple MG, Lim WS, et al. Predictors of clinical outcome in a national hospitalised cohort across both waves of the influenza A/H1N1 pandemic 2009-2010 in the UK. Thorax 2012;67:709-17.

[30] Dunning A, DiazGranados C, Voloshen T, et al. Correlates of protection against influenza in the elderly: results from an influenza vaccine efficacy trial. Clin Vaccine Immunol 2016;23(3):228-35.

[31] DiazGranados CA, Dunning AJ, Kimmel M, et al. Efficacy of high-dose versus standard-dose influenza vaccine in older adults. N Engl J Med 2014;371(7):635-45, http://dx.doi.org/10.1056/NEJMoa1315727.

[32] Shaw MW, Xu X, Li Y, Normand S, Ueki RT, Kunimoto GY, et al. Reapparence and global spread of variants of influenza B/Victoria lineage viruses in the 2000-2001 and 2001-2002 seasons. Virology 2002.

[33] Falsey AR, Murata Y, Walsh EE. Impact of rapid diagnosis on management of adults hospitalized with influenza. Arch Intern Med 2007;167:354e60.

[34] González-Del Vecchio M, Catalán P, de Gea V, Rodríguez-Borlado A, Martos C, Padilla B, et al. An algorithm to diagnose influenza infection: evaluating the clinical importance and impact on hospital costs of screening with rapid antigen detection tests. Eur J Clin Microbiol Infect Dis 2015;34(6):1081-5. 
[35] Chartrand C, Leeflang MMG, Minion J, Brewer T, Pai M. Accuracy of rapid influenza diagnostic tests: a meta-analysis. Ann Intern Med 2012;156(7):500-11.

[36] Cho CH, Woo MK, Kim JY, Cheong S, Lee C-K, An SA, et al. Evaluation of five rapid diagnostic kits for; influenza A/B virus. J Virol Methods 2013;187(1):51-6.

[37] Ruest A, Michaud S, Deslandes S, Frost EH. Comparison of the Directigen flu A + B test, the QuickVue influenza test, and clinical case definition to viral culture and reverse transcription-PCR for rapid diagnosis of influenza virus infection. J Clin Microbiol 2003;41(8):3487-93.

[38] Salez N, Nougairede A, Ninove L, Zandotti C, de Lamballerie X, Charrel RN. Prospective and retrospective evaluation of the Cepheid Xpert ${ }^{\circledR}$ Flu/RSV XC assay for rapid detection of influenza A, influenza B, and respiratory syncytial virus. Diagn Microbiol Infect Dis 2015;81(4): 256-8. 